\title{
PERHITUNGAN NILAI PENDEKATAN TRIGONOMETRI DAN TRIGONOMETRI INVERS SECARA MANUAL
}

\author{
Moh. Affaf \\ STKIP PGRI Bangkalan, mohaffaf@stkippgri-bkl.ac.id
}

\begin{abstract}
Abstrak-Pada pengaplikasiannya, perhitungan nilai trigonometri maupun inversnya, hampir keseluruhan pengguna menggantungkan masalah perhitungan ini pada kalkulator scientific. Dalam makalah ini, akan diajukan sebuah metode untuk menghitung nilai trigonometri beserta inversnya dengan cara manual, yaitu hanya dengan memanfaatkan operasi jumlah, kurang, kali, atau bagi. Dengan ini, diharapkan para pengguna/pengaplikasi tidak lagi bergantung pada kalkulator scientific dalam menyelesaikan masalah perhitungan nilai trigonometri maupun inversnya.
\end{abstract}

Kata kunci: Metode Numerik, Trigonometri, Trigonometri Invers.

\section{PENDAHULUAN}

Trigonometri adalah salah satu cabang matematika yang mempelajari tentang ukuran segitiga dengan menggunakan konsep sinus dan cosinus. Trigonometri baru dikenalkan di sekolah pada tingkat siswa menengah pertama atau sederajat pada semester kedua tingkat akhir. Pada tingkat ini, siswa masih dikenalkan pada definisi sinus dan cosinus serta beberapa penggunaan dasarnya. Dalam tingkat ini pula, siswa hanya dikenalkan tentang nilai sinus dan cosinus untuk sudut istimewa saja.

Pada sekolah tingkat atas atau sederajat, para siswa akan dihadapi pada masalah yang membutuhkan perhitungan nilai trigonometri maupun inversnya, baik itu studi tentang Matematika, Fisika, Teknik, maupun tentang Astronomi. Hampir dalam semua permasalahan, jarang sekali melibatkan sudut-sudut istimewa. Dalam menghadapi hal ini, hampir seluruh pengguna menggantungkan masalah perhitungan ini pada kalkulator scientific.

Dilain pihak, telah diketahui bahwa tidak ada nilai eksak secara numerik untuk beberapa sudut untuk nilai sinus dan cosinus [1]. Hal ini memberikan penjelasan bahwa nilai yang diberikan kalkulator untuk sinus dan cosinus merupakan suatu nilai pendekatan. Dengan kata lain, nilai pendekatan tersebut 
juga diperoleh melalui proses operasi biasa/ manual, yaitu hanya dengan menggunakan operasi tambah, kurang, kali, dan bagi. Oleh karena itu, Tsige [2] memberikan sebuah metode yang cukup mudah untuk menentukan nilai trigonometri atau inversnya, yaitu hanya dengan melihat nilai sudut atau arc yang diminta. Disini Tsige bahkan hanya menggunakan operasi perkalian saja untuk mendapatkan nilai trigonometri maupun inversnya. Selain itu, Radhskrishnan [3] juga memberikan pendekatan nilai trigonometri dengan metode yang sederhana, yaitu hanya dengan memanfaatkan beberapa rumus trigonometri pada sekolah tingkat atas. Dalam metodenya ini, Radhsrisnan menggunakan keempat operasi manual, yaitu operasi tambah, kurang, kali, dan bagi.

Untuk metode yang diajukan oleh Radhskrishnan, iterasi/proses yang dilakukan adalah 16 kali iterasi dengan taraf ketelitian sampai tiga angka dibelakan koma. Bagi peneliti, taraf ketelitian tersebut terlalu kecil untuk 16 iterasi. Dengan kata lain, peneliti merasa bahwa metode tersebut masih dapat diperbaiki sehingga iterasi yang dilakukan sesedikit mungkin.

Dari latar belakang yang telah disebutkan di atas, maka permasalahan yang diangkat dalam penelitian ini adalah memodifikasi metode Radhskrishnan sehingga iterasi yang dilakukan untuk mencapai ketelitian tiga angka dibelakang koma dapat diminimalkan. Dengan begitu, maka metode ini dapat digunakan siswa untuk menentukan nilai trigonometri dan inversnya dan hanya memerlukan waktu yang relatif singkat.

\section{METODE PENELITIAN}

Seperti yang telah dijelaskan sebelumnya, penelitian ini bertujuan untuk menjelaskan kepada siswa bahwa semua nilai trigonometri maupun trigonometri invers dalam kalkulator scientific merupakan nilai yang proses perhitungannya hanya memanfaatkan operasi yang sudah sangat mereka kenal selama ini, yaitu operasi tambah, kurang, kali, dan bagi. Oleh karena itu, dalam penelitian ini akan diajukan sebuah prosedur perhitungan nilai pendekatan trigonometri dan inversnya. Dengan demikian, siswa dapat melihat bagaimana proses kerja kalkulator sehigga mendapatkan nilai pendekatan yang diinginkan. Selain itu, dengan prosedur ini, diharapkan siswa tidak bergantung lagi pada kalkulator 
scientific dalam menghitung atau menentukan nilai trigonometri maupun inversnya dalam memecahkan masalah yang berkaitan dengan trigonometri, seperti yang sudah dijelaskan dalam urgensi penelitian ini. Dengan kata lain, diharapkan siswa dapat menggunakan prosedur atau metode yang diajukan dalam penelitian ini dalam menghitung nilai trigonometri maupun inversnya secara manual.

Pada 2008, Radhskrishnan memberikan metode yang sederhana dalam menentukan pendekatan nilai trigonometri. Metode ini dikatakan sederhana karena hanya dengan memanfaatkan beberapa rumus trigonometri pada sekolah tingkat atas. Dalam metodenya, Radhskrishnan hanya menentukan nilai cosinus. Untuk menentukan nilai sinus, Radhskrishnan mengubahnya terlebih dahulu menjadi cosinus. Untuk metode yang diajukan oleh Radhskrishnan, iterasi/proses yang dilakukan adalah 16 kali iterasi dengan taraf ketelitian sampai tiga angka dibelakan koma.

Adapun langkah-langkah dari metode Radhskrishnan dalam menentukan nilai pendekatan dari trigonometri adalah sebagai berikut.

1. Misalkan akan ditentuan nilai dari $\sin x^{\circ}$, maka terlebih dahulu ubahlah $\sin x^{\circ}$ menjadi $\cos y^{\circ}$, dimana nilai $y$ adalah di antara 0 dan 90 . Jika yang akan dihitung $\cos x^{\circ}$, maka terlebih dahulu ubahlah $\cos x^{\circ}$ menjadi $\cos y^{\circ}$, dimana nilai $y$ adalah di antara 0 dan 90 .

2. Tuliskan $y$ sebagai $y_{0}$. Selanjutnya, bentuklah barisan $y_{1}, y_{2}, y_{3}, \ldots, y_{16}$ dengan aturan sebagai berikut.

a. $y_{i}=2 y_{i-1}$ jika $y_{i-1}$ kurang dari 45 ,

b. $y_{i}=180-2 y_{i-1}$ jika $y_{i-1}$ lebih dari atau sama dengan 45 .

3. Pilihlah sebarang nilai diantara 0 dan 1 untuk diberikan kepada $\cos y_{16}{ }^{\circ}$.

4. Untuk nilai $\cos y_{i}^{\circ}$ dengan $i=0,1,2,3, \ldots, 15$ ditentukan dengan aturan sebagai berikut.

a. Hitung nilai $\cos y_{i}^{\circ}=\sqrt{\frac{1+\cos y_{i+1}^{\circ}}{2}}$ jika nilai $y_{i}$ kurang dari 45 ,

b. Hitung nilai $\cos y_{i}^{\circ}=\sqrt{\frac{1-\cos y_{i+1}^{\circ}}{2}}$ jika nilai $y_{i}$ lebih dari atau sama dengan 45 . 
Maka, $\cos y_{0}{ }^{\circ}$ adalah nilai pendekatan untuk $\sin x^{\circ}$ atau $\cos x^{\circ}$ yang dimaksud.

Untuk menghitung nilai pendekatan trigonometri, Radhs memberikan langkah-langkah dari metodenya sebagai berikut.

1. Misalkan akan ditentuan nilai dari $\arcsin x$, maka tuliskan $y=\sqrt{1-x^{2}}$. Jika yang akan dihitung $\arccos x$, maka tuliskan $y=x$.

2. Tuliskan $y$ sebagai $y_{0}$. Selanjutnya, bentuklah barisan $y_{1}, y_{2}, y_{3}, \ldots, y_{16}$ dengan aturan sebagai berikut.

$$
y_{i}=2 y_{i-1}^{2}-1
$$

3. Pilihlah sebarang nilai diantara 0 dan 90 untuk diberikan kepada $\arccos y_{16}$.

4. Untuk nilai $\arccos y_{i}$ dengan $i=0,1,2,3, \ldots, 15$ ditentukan dengan aturan sebagai berikut.

a. Hitung nilai $\arccos y_{i}^{\circ}=\frac{180-\arccos y_{i+1}}{2}$ jika nilai $y_{i}$ kurang dari 0,7071 ,

b. Hitung nilai $\arccos y_{i}^{\circ}=\frac{\arccos y_{i+1}}{2}$ jika nilai $y_{i}$ lebih dari atau sama dengan 0,7071 .

Maka, $\arccos y_{0}^{\circ}$ adalah nilai pendekatan untuk $\arcsin x^{\circ}$ atau $\operatorname{arc} \cos x^{\circ}$ yang dimaksud.

Seperti yang telah dijelaskan sebelumnya, penelitian ini bertujuan untuk menjelaskan kepada siswa bahwa semua nilai trigonometri maupun trigonometri invers dalam kalkulator scientific merupakan nilai yang proses perhitungannya hanya memanfaatkan operasi yang sudah sangat mereka kenal selama ini, yaitu operasi tambah, kurang, kali, dan bagi. Oleh karena itu, dalam penelitian ini akan diajukan sebuah prosedur perhitungan nilai pendekatan trigonometri dan inversnya. Dengan demikian, siswa dapat melihat bagaimana proses kerja kalkulator sehigga mendapatkan nilai pendekatan yang diinginkan. Selain itu, dengan prosedur ini, diharapkan siswa tidak bergantung lagi pada kalkulator scientific dalam menghitung atau menentukan nilai trigonometri maupun inversnya dalam memecahkan masalah yang berkaitan dengan trigonometri, 
seperti yang sudah dijelaskan dalam urgensi penelitian ini. Dengan kata lain, diharapkan siswa dapat menggunakan prosedur atau metode yang diajukan dalam penelitian ini dalam menghitung nilai trigonometri maupun inversnya secara manual.

Langkah yang dilakukan untuk membangun prosedur ini adalah dengan cara membentuk himpunan A, yaitu

$$
A=\{0,3.75,7.5,11.25,15,18.75,22.5,26.25,30,33.75,37.5,41.25,45\}
$$

untuk prosedur perhitungan nilai pendekatan trigonometri dan membentuk himpunan B, yaitu

$$
\begin{aligned}
B= & \{\cos 0, \cos 3.75, \cos 7.5, \cos 11.25, \cos 15, \cos 18.75, \cos 22.5, \cos 26.25, \cos 30\} \cup \\
& \{\cos 33.75, \cos 37.5, \cos 41.25, \cos 45\}
\end{aligned}
$$

untuk prosedur perhitungan nilai pendekatan trigonometri invers.

\section{HASIL DAN PEMBAHASAN}

Pada bagian ini akan dijelaskan perbaikan dari prosedur Radhs, baik dalam prosedur perhitungan nilai pendekatan trigonometri maupun dalam prosedur perhitungan nilai pendekatan trigonometri invers.

Berikut ini adalah langkah perbaikan dari prosedur perhitungan nilai pendekatan trigonometri.

1. Misalkan akan ditentuan nilai dari $\sin x^{\circ}$, maka terlebih dahulu ubahlah $\sin x^{\circ}$ menjadi $\cos y^{\circ}$, dimana nilai $y$ adalah di antara 0 dan 90. Jika yang akan dihitung $\cos x^{\circ}$, maka terlebih dahulu ubahlah $\cos x^{\circ}$ menjadi $\cos y^{\circ}$, dimana nilai $y$ adalah di antara 0 dan 90 .

2. Tuliskan $y$ sebagai $y_{0}$. Selanjutnya, bentuklah barisan $y_{1}, y_{2}, y_{3}, \ldots, y_{8}$ dengan aturan sebagai berikut.
a. $y_{i}=2 y_{i-1}$ jika $y_{i-1}$ kurang dari 45 ,
b. $y_{i}=180-2 y_{i-1}$ jika $y_{i-1}$ lebih dari atau sama dengan 45 .

3. Tentukan $a, b \in A$ sehingga $a<\frac{y_{8}}{2}<b$ sehingga tidak ada $c \in A$ yang memenuhi $a<c<b$. Maka tuliskan $\cos {y_{8}}^{\circ}=\cos b^{\circ}$. 
4. Untuk nilai $\cos y_{i}^{\circ}$ dengan $i=0,1,2,3, \ldots, 8$ ditentukan dengan aturan sebagai berikut.

a. Hitung nilai $\cos y_{i}^{\circ}=\sqrt{\frac{1+\cos y_{i+1}^{\circ}}{2}}$ jika nilai $y_{i}$ kurang dari 45 ,

b. Hitung nilai $\cos y_{i}^{\circ}=\sqrt{\frac{1-\cos y_{i+1}^{\circ}}{2}}$ jika nilai $y_{i}$ lebih dari atau sama dengan 45 .

Maka, $\cos y_{0}{ }^{\circ}$ adalah nilai pendekatan untuk $\sin x^{\circ}$ atau $\cos x^{\circ}$ yang dimaksud.

Selanjutnya, untuk langkah perbaikan dari prosedur perhitungan nilai pendekatan trigonometri invers adalah sebagai berikut.

1. Misalkan akan ditentuan nilai dari $\arcsin x$, maka tuliskan $y=\sqrt{1-x^{2}}$. Jika yang akan dihitung $\arccos x$, maka tuliskan $y=x$.

2. Tuliskan $y$ sebagai $y_{0}$. Selanjutnya, bentuklah barisan $y_{1}, y_{2}, y_{3}, \ldots, y_{8}$ dengan aturan sebagai berikut.

$$
y_{i}=2 y_{i-1}^{2}-1
$$

3. Tentukan $a, b \in B$ sehingga $a<\sqrt{\frac{1+\cos y_{8}^{\circ}}{2}}<b$ sehingga tidak ada $c \in B$ yang memenuhi $a<c<b$. Maka tuliskan $\arccos y_{8}=\arccos a$.

4. Untuk nilai $\arccos y_{i}$ dengan $i=0,1,2,3, \ldots, 8$ ditentukan dengan aturan sebagai berikut.

a. Hitung nilai $\arccos y_{i}=\frac{180-\arccos y_{i+1}}{2}$ jika nilai $y_{i}$ kurang dari 0,7071

b. Hitung nilai $\arccos y_{i}=\frac{\arccos y_{i+1}}{2}$ jika nilai $y_{i}$ lebih dari atau sama dengan 0,7071 .

Maka, $\arccos y_{0}^{\circ}$ adalah nilai pendekatan untuk $\arcsin x^{\circ}$ atau $\operatorname{arc} \cos x^{\circ}$ yang dimaksud. 


\section{KESIMPULAN DAN SARAN}

Dari bab 3 di atas, dapat disimpulkan bahwa dengan cara memilih nilai pada langkah ketiga sebagai nilai dari trigonometri atau trigonometri invers rangkapnya, maka iterasi pada prosedur Radhs dapat dikurangi menjadi separuhnya. Meskipun demikian, tetap diperoleh taraf ketelitian yang sama, yaitu 0,0009 .

Untuk selanjutnya, penelitian ini dapat dilanjutkan. Permasalahan yang dapat diangkat salah satunya adalah mungkinkah mengurangi lagi iterasi yang sudah ada pada penelitian ini sehingga tetap di[eroleh ketelitian yang sama ataupun lebih baik.

\section{DAFTAR PUSTAKA}

[1] Herstein, I.R. 1996. Abstract Algebra. New York: John Wiley and Sons.

[2] Radhskrisnan, J. 2008. A Method for Finding trigonometric value and its inverse. India.

[3] Tsige, M.G. 2013. Some Applicable Methods of Approximating Basic Trigonometric Function and Their Inverse Value. International Journal of Scientific \& Technology Research Volume 2, Issue 12, December 2013. ISSN 2277-8616. 